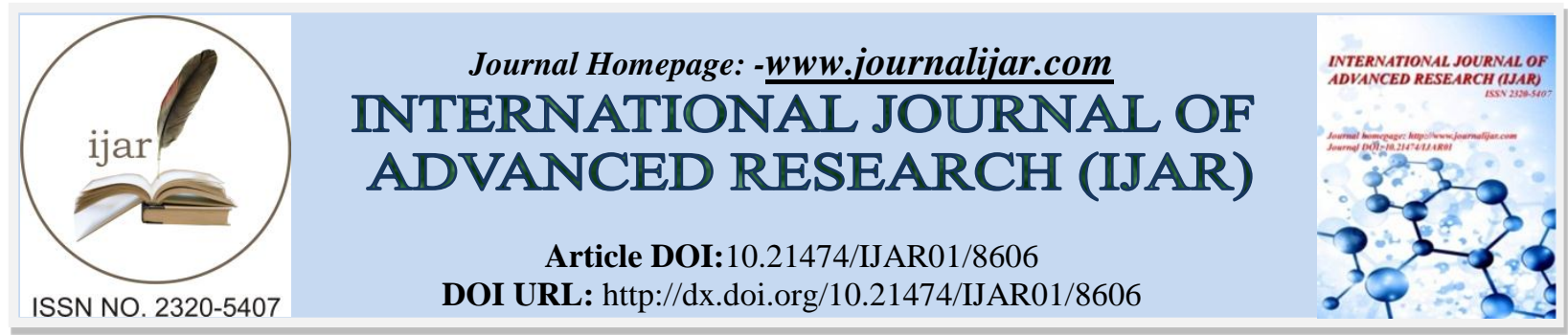

RESEARCH ARTICLE

\title{
A GEO SPATIAL ANALYSIS OF FLOOD HAZARD IMPACT ASSESSMENT IN VAVUNIYA DISTRICT, SRI LANKA.
}

V. Sivarajah ${ }^{1}$, J. N. D. Jayathunga ${ }^{1}$ and S. Thiyagarajah ${ }^{2}$.

1. Assistant Lecturer, Department of Geography, University of Colombo, Sri Lanka.

2. Faculty of Graduste Studies, University of Sri Jayawardanapura, Sri Lanka.

\section{Manuscript Info}

Manuscript History

Received: 04 January 2018

Final Accepted: 06 February 2019

Published: March 2019

Key words:-

Flood hazard, Flood risk mapping, Geo spatial, Impact assessment, Multi-criteria decision approach.

\section{Abstract}

Several areas in the Vavuniya district are being experienced to inundate during every rainy season frequently, thus it is crucial to assess the flooding incidents in this area in order to derive the proper planning and policies to overcome the impact of this hazard. The objective of this study was to build a GIS model for flood hazard impact assessment in Vavuniya district of Northern Province. In addition to produce flood hazard risk map to the Vavuniya district in a GIS platform. The study has required primary data, were collected from observations, discussions and interviews with affected people using district level participatory hazard and resource mapping. secondary data has been collected from reports, disaster preparedness and response plan in Disaster Management Center. The present investigation was tailored to assess the use of Multi Criteria Decision Approach (MCDA) in Vavuniya district flood analysis. Categorization of possible flood risk zone was accomplished using geospatial datasets like elevation, slope, distance from river, and land use characteristics which were derived from digital elevation model (DEM) and satellite image respectively. As well as, data were collected using hazard score, vulnerability score, and manageability score tables and produced risk map in Vavuniya district. This result suggests that MCDA within GIS techniques is very useful in accurate and reliable flood risk analysis and mapping. In this context it is critical to develop appropriated preventive strategies in the flood prone zone to protect the people from potential disaster threat. The Hazard score map with spatial references Vavuniya north, Vavuniya, and Vengalacheddikulam are high hazard prone areas in Vavuniya district. The vulnerability score map with spatial references Vavuniya north, Vavuniya and Vengalacheddikulam are highly vulnerable areas in Vavuniya district. The manageability score map with spatial references Vavuniya north, Vavuniya, and Vengalacheddikulam are highly hazard prone areas in the district. The risk score map with spatial references Vavuniya, Vavuniya south and Vengalacheddikulam are highly hazard prone areas in Vavuniya district. 


\section{Introduction:-}

Flooding is arguably the hydrological related hazard. That is most widespread around the globe. A flood is a general and temporary condition where two or more acres of normally dry land or two or more properties are inundated by water and mudflow. Flooding is often thought of as a result of heavy rainfall, but floods can arrive in a number of ways that are not directly related to ongoing weather events. Nevertheless, it is clear that in some ultimate sense, the water that is involved in flooding has been fallen as precipitation at some time, perhaps long ago, the origins of flooding, therefore, ultimately since in atmospheric processes creating precipitation, no matter what event caused the flooding.

Flood can be generally classified into four types a) Costal floods, b) Flash floods, c) River floods, d) Urban floods, e) Cloud burst (D Lowe, 2013). Impacts of flood disaster on the society and its effect on sustainable development are over whelming in recent years. The international Red Cross organization estimates that on overage, 66 million people suffer from flood damage, either directly or indirectly each year (Doocy et al, 2005).

More than half of global flood damages occur in Asia. Floods are major natural hazards in the Southeast Asian region. For Example, in Bangladesh one of the most flood prone countries in the Asian region, as many as 80 million people are vulnerable Manu dramatic flood events have been recorded historically mostly induced by tropical cyclones or seasonal rains, such as the tropical storms in Bangladesh in April 1991 caused 130000 death and the summer floods of 1998 in China that resulted in material damage costing us dollars 30 billion. Floods also cause loss of top soil which affected the fertility of land (Christenson et al, 2014). Storm floods in India. The Mumbai flood after the unprecedented rain fall of $994 \mathrm{~mm}$ on 26-27 July 2005 caused about 1000 deaths and US dollars 750 million in economic losses. This case is particularly good for investigating rain- induced flood disaster (RodriguezLlanes, 2016).

Now a day, Number of victims and areas by flood hazard are increasing in the world so that, Variety of management system are considered to reduce it. For example, in most developing countries, flood disaster management activities are handled by government. Participation of nongovernmental agencies and private sectors are very limited. Activities are exercised rather independently without proper coordination or integration. Flood disaster management in developing countries is mostly reactive responding to prevailing disaster situations (emergency response and recovery). Reactive response should be changed to proactive response to increase effectiveness of management and reduce losses of life and properties. Proactive disaster management requires more participation from various governments, non- governmental and private agencies and public participation. It involves more effort and time, more budget, equipment, facilities and human resources which leads to integration of flood disaster management for both long term and short-term activities. Strategic frame work on integrated flood disaster management includes four cyclic steps namely:

1. Preparedness before flood impact such as flood forecasting and warning

2. Readiness upon flood arrival

3. Emergency responses during flood impact and

4. Recovery and rehabilitation after flood impact

Examples on urban flood disaster and risk management Conclusions and recommendations for further improvement are provided.

Sri Lanka also affected in the flood hazard. Flood is a most vulnerable and frequency occur natural hazard in Sri Lanka. Sri Lanka has caused heavy rains across the country since 14th May 2016 (Divisional Secretariat Department, 2015). This has triggered flood situation in the country. Which affected thousands of lives and livelihoods and damage to properties according to the Disaster Management Center (DMC) on 19 may 201612 hours, 22 districts out of 25 districts have been reported be affected by the heavy rains and subsequent impacts Colombo, Gampaha, Kegalle, Puttalam and Kurunegala districts are highly affected districts. The causes of floods are due to natural factors such as heavy rainfall, high floods, and high tides, etc., and human factors such as blocking of channel or aggravation of drainage channels, improper land use, deforestation in head water region, etc. Floods result in losses of life and damage properties. With the current and growing hazards flooding poses to society, there must be a greater capability to manage floods and mitigate losses.

In the developmental context of Sri Lanka, there has been a greater focus on the issues pertaining to natural and manmade disasters. Occurrences of flood have had significant impact on many sectors in the region. Vavuniya 
district is endowed for its rich cascade system in Northern province Sri Lanka. It is one of the districts which frequency affected by flooding with following heavy rain during rainy seasons.

In this context there have been hardly any investigations conducted in Vavuniya district related to flooding incidents. Unplanned urbanization, Extensive encroachment and improper management of tanks during past decades have been made the flood inundation more severe in Vavuniya district. There is a need to study the impact of the identify the spatial and temporal patterns; assess the impact of flood hazard, to build GIS Model for flood hazard Impact Assessment. Finding of the study are useful for the future investment in the field and think dynamically.

\section{Study Area}

The research area is Vavuniya district in Northern Province. The Vavuniya district in the Northern part of Sri Lanka. It covers of an area about 1966.90square kilometers. These consist for $10 \%$ of the land area in the entire Northern East province. Vavuniya division is located in the middle part of the Vavuniya district and bounded by Vavuniya, Vavuniya South, Vavuniya North, Venkalacheddikulam. (Map no.1) The Vavuniya district between geographical coordinates longitudes $80^{\circ} 28^{\prime}-80^{\circ} 32^{\prime}$ and latitudes $8^{\circ} 43^{\prime}-8^{\circ} 48^{\prime}$. Administratively this district constitutes part of Wanni Electoral District. This district has 4 divisional secretariats and covers 102 Grama Niladharies division. There are 5 Local Bodies functioning in the district. Such as one Urban Council and four divisional secretariats too.

Map no.1:-Map of the Study Area

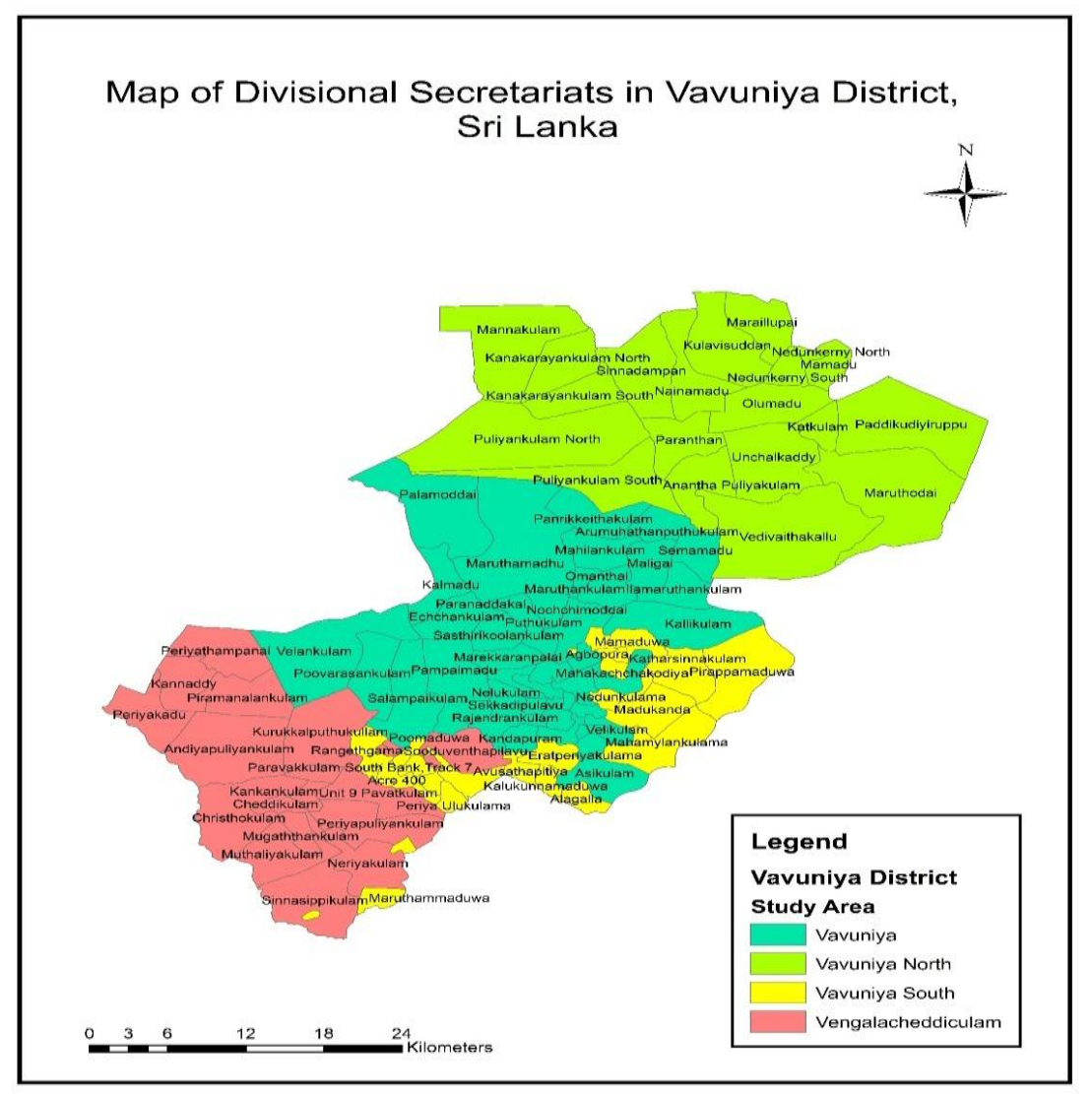

Source: Prepared by author using geographic information system, 2018

The total population of this district is nearly 171511 according to the census year in 2011. Density of the population is 87 persons per Sq.km in Vavuniya District in 2011. The majority of the resident's livelihood is Agriculture. Vavuniya district is predominantly and agricultural district with unique cascade systems. There are 1 major, 22 medium and 711 minor irrigation tanks. The water resources mainly depend on rain fall as there are no perennial rivers. Out of the 742 minor irrigation schemes, 69 are abandoned. The water flows center to the minor rivers of the district from Kanakarayan river, Parangiyen river, and Pali river during the maha season paddy dependence of rain. 
Recent survey indicated that $38 \%$ of the total land is engaged in agriculture and $47 \%$ of the land is forest cover. About 21,000 ha. Land is used for paddy cultivation of which 11,000 ha is irrigated by minor irrigation schemes. In addition to this there are about 10,000 ha. During the rainy season almost, farmers grown highland rice which forms the staple diet of the people. Normally the farmers use 1/3 of their lands for cultivating rice during the wet season. The rest remains under vegetables and subsidiary cash crops. Although these subsidiary crops give way to rice during the maha seasons, they become the dominant crops during the maha seasons and during the yala season. The vegetation in the area around Vavuniya basically deciduous dry zone topical forest type. Although much of the natural vegetation is now modified by agricultural activities, large tracts of forest lands are still a common sight. The soil of the district is highly fertile due to reddish brown earth, low humid clays and alluvial soil. There are concave valley and bottomlands. Red- Yellow latro soils are found in the Northern part of the district, and that area is more fertile and has better ground water potential. In the other part of the district, there are hard crystalline rocks with limited ground water potential that determine the substrata. Vavuniya district is located in low county dry zone of Sri Lanka. The average temperature in Vavuniya is $27.4^{\circ} \mathrm{c}$ about $1434 \mathrm{~mm}$ of precipitation falls annually.

\section{Methodology: -}

The main purpose of this research was to study the applicability of Geo - spatial techniques on flood hazard impact assessment in Vavuniya district, to identify the spatial temporal patterns of flood hazard, to assess the impact of flood hazard, to build GIS model for flood hazard impact assessment. The research work especially carried out in the Vavuniya district. In Sri Lanka Vavuniya facing flood hazard every year and it is the third major city of facing flooding annually. Because of having more big ponds, river surrounding and the soil type of the city.

\section{Data and Sources of Data}

Data collection and data basing required for Hazard analysis and Vulnerability analysis. The Flood Risk analysis and impact assessment were carried out Hazard analysis consists of Multi Criteria Decision approach (MCDA) and Satellite data analysis.

Information has been gathered through primary data and secondary data. Primary data have been gathered through the field visit in the Flood Risk areas, field observation, conducting discussions and interviews from DMC officers and affected people from flood hazard. Field survey conducted by using participatory hazard and resource mapping and interviews in GN divisions, DS divisions. Secondary data - Statistical hand book (Vavuniya DS division), Rain fall data, Flood incidents from 2010 - 2016 were collected from Vavuniya Divisional secretariat department, Disaster Management Center Report, Paddy damages in Agriculture department report, Details of seasonal details in Survey department, population density Vavuniya Divisional secretariat department.

\section{Theoretical framework}

Identification of possible flood risk zones was performed using geospatial data sets like elevation, slope, distance to river, and land use. These parameters were derived from Digital Elevation Model (DEM) and topographical map respectively. Topographical map was used to digitize river lines in the study area. ASTER provides topographic data in $25 \mathrm{~m}$ spatial resolution. All other details of the data sets are given in the table.

Normalized weight index (NWI) was calculated using total weight dividing with individual weight as shown in Table no:1. This table shows the detailed analysis adopted in this research.

Table no 1:-Rate, Normalized Rating Index, Weighted Index based on MCDA

\begin{tabular}{|c|c|c|c|c|c|}
\hline Parameters & $\begin{array}{l}\text { Category/ } \\
\text { Class }\end{array}$ & Rate & $\begin{array}{l}\text { Normalized } \\
\text { Rating Index } \\
\text { (NRI) }\end{array}$ & Weight & $\begin{array}{l}\text { Normalized } \\
\text { Weight } \\
\text { Index } \\
\text { (NWI) }\end{array}$ \\
\hline
\end{tabular}




\begin{tabular}{|c|c|c|c|c|c|}
\hline Elevation (m) & $\begin{array}{l}0-25 \\
25-50 \\
50-75 \\
75-100 \\
100 \text { more }\end{array}$ & $\begin{array}{l}5 \\
4 \\
3 \\
2 \\
1 \\
15\end{array}$ & $\begin{array}{l}0.3 \\
0.26 \\
0.2 \\
0.13 \\
0.06\end{array}$ & 2 & 0.2 \\
\hline $\begin{array}{l}\text { Slope } \\
\text { (Degree) }\end{array}$ & $\begin{array}{l}0-0.3 \\
0.3-1.1 \\
1.1-2.3 \\
2.3-4.6 \\
4.6 \text { more }\end{array}$ & $\begin{array}{l}5 \\
4 \\
3 \\
2 \\
1 \\
15\end{array}$ & $\begin{array}{l}0.3 \\
0.26 \\
0.2 \\
0.13 \\
0.06\end{array}$ & 3 & 0.3 \\
\hline $\begin{array}{l}\text { Distance } \\
\text { from } \\
\text { River(m) }\end{array}$ & $\begin{array}{l}0-39 \\
39-130 \\
130-592 \\
592-2520 \\
5600 \text { more }\end{array}$ & $\begin{array}{l}5 \\
4 \\
3 \\
2 \\
1 \\
15\end{array}$ & $\begin{array}{l}0.3 \\
0.26 \\
0.2 \\
0.13 \\
0.06\end{array}$ & 4 & 0.4 \\
\hline Land Use & $\begin{array}{l}\text { Forest } \\
\text { Paddy } \\
\text { Water } \\
\text { Chena Grass } \\
\text { Land }\end{array}$ & $\begin{array}{l}5 \\
4 \\
3 \\
2 \\
1 \\
15\end{array}$ & $\begin{array}{l}0.3 \\
0.26 \\
0.2 \\
0.13 \\
0.06\end{array}$ & 1 & 0.1 \\
\hline
\end{tabular}

Source: Prepared by author, 2018.

The most important factor in determining flood hazard is flood frequency which gives the better understanding of the risk by flooding. Flood occurrences in each GN division for the period of 7 years were shown in flood occurrence. Vavuniya town and Vavuniya North has recorded high Flood occurrence from 2010 - 2016. However, the whole area had affected by flooding at least once in 7 year. (Map no.2)

Map no 2:-Flood Occurrences in the Study Area

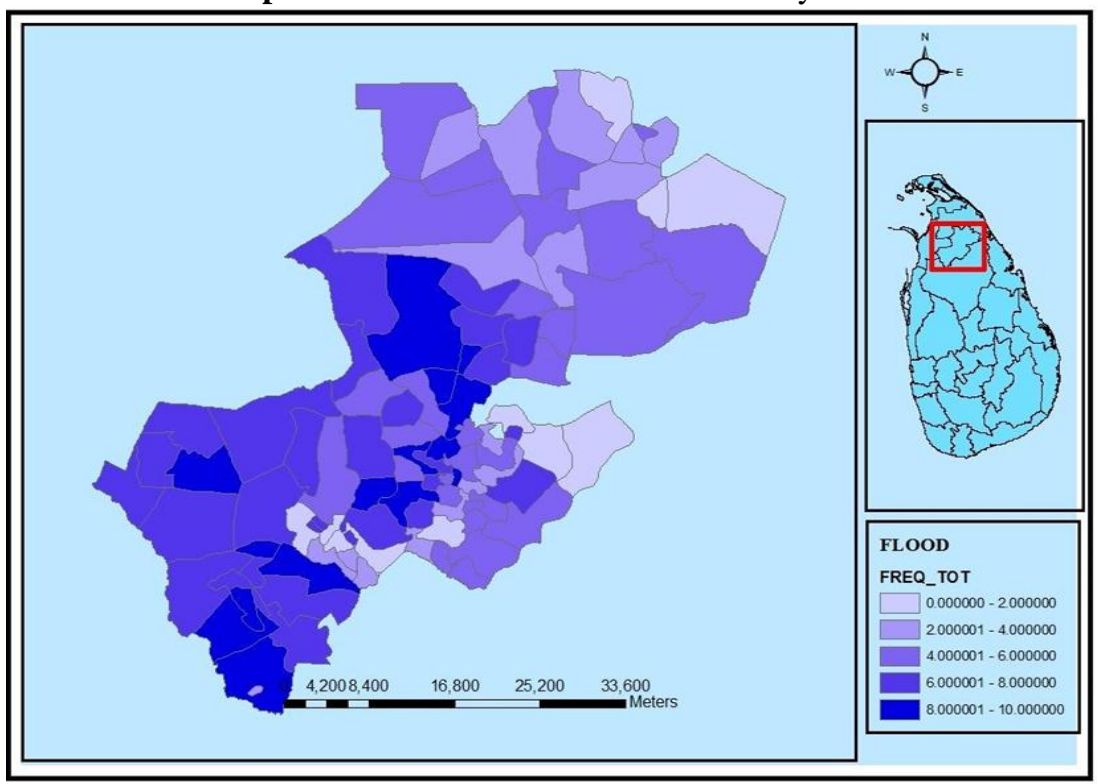

Source: Prepared by author using digital data collected from survey department of Sri Lanka, 2018 
In addition to primary data were collected from some interviews and discussion in DSD wise. The data analysis consists of data collection and data basing required for hazard analysis, vulnerability analysis, manageability analysis based on the hazard score, vulnerability score, manageability score and risk score carried out.

This consideration of the elements GN was calculated as additive model by using the entire specified variable.

$$
\text { RISK SCORE }=\frac{\text { HAZARD SCORE X VULNERABILITY SCORE }}{\text { MANAGEABILITY SCORE }}
$$

\section{Hazard Assessment}

Hazard means the probability of occurrence within a specified period of time in a given area and potentially damaging natural phenomenon. Flood hazard is categorized based on the level of difficulties in daily life to properties. Flood hazard assessment is the estimation of overall adverse effects of flooding. It depends on many parameters. The hazard assessment was consideration of this elements such as how much area of GN affected, do you expect the flood hazard to occur with the next, how severe or potentially damaging, how long could the last, occur and time. One or more parameters can be considered in the hazard assessment. In the present study, depth of hazard was considered for flood hazard assessment.

\begin{tabular}{|c|c|c|c|c|c|c|c|c|c|c|c|c|c|c|c|}
\hline \multicolumn{3}{|c|}{$\begin{array}{l}\text { How much area of } \\
\text { GN affected }\end{array}$} & \multicolumn{3}{|c|}{$\begin{array}{l}\text { Do you expect } \\
\text { the hazard to } \\
\text { occur within } \\
\text { the next }\end{array}$} & \multicolumn{3}{|c|}{$\begin{array}{l}\text { How severe } \\
\text { or } \\
\text { potentially } \\
\text { damaging? }\end{array}$} & \multicolumn{3}{|c|}{$\begin{array}{l}\text { How long } \\
\text { could the } \\
\text { last? }\end{array}$} & \multicolumn{2}{|c|}{$\begin{array}{c}\text { Could it } \\
\text { occur and } \\
\text { time or is it } \\
\text { more } \\
\text { predictable } \\
?\end{array}$} & \multicolumn{2}{|c|}{$\begin{array}{c}\text { Calculatio } \\
\text { n on }\end{array}$} \\
\hline $\begin{array}{l}\text { Alm } \\
\text { ost } \\
\text { entir } \\
\text { e } \\
(10)\end{array}$ & $\begin{array}{l}\text { Ab } \\
\text { out } \\
\text { a } \\
\text { hal } \\
\text { f } \\
(05 \\
)^{2}\end{array}$ & $\begin{array}{l}\text { A } \\
\text { qua } \\
\text { rter } \\
\text { or } \\
\text { less } \\
(01 \\
\text { (01 }\end{array}$ & $\begin{array}{l}\text { O } \\
\text { ne } \\
\text { Y } \\
\text { ea } \\
\text { r } \\
(1 \\
0)\end{array}$ & $\begin{array}{l}\text { Fi } \\
\text { ve } \\
\text { Y } \\
\text { ea } \\
\text { r } \\
(0 \\
5)\end{array}$ & $\begin{array}{l}\text { T } \\
\text { en } \\
Y \\
\text { ea } \\
\text { r } \\
(0 \\
1)\end{array}$ & $\begin{array}{l}\text { Ve } \\
\text { ry } \\
\text { Hi } \\
\text { gh } \\
(1 \\
0)\end{array}$ & $\begin{array}{l}\text { Mode } \\
\text { rate } \\
(05)\end{array}$ & $\begin{array}{l}\mathrm{Mi} \\
\mathrm{ld} \\
(0 \\
1)\end{array}$ & $\begin{array}{c}1 \\
\mathrm{We} \\
\mathrm{ek} \\
(10 \\
)\end{array}$ & $\begin{array}{l}3 \\
\mathrm{Da} \\
\text { ys } \\
(0 \\
5)\end{array}$ & $\begin{array}{l}1 \\
\mathrm{D} \\
\text { ay } \\
(0 \\
1)\end{array}$ & $\begin{array}{l}\text { A } \\
\text { ny } \\
\text { Ti } \\
\text { m } \\
\text { e } \\
(1 \\
0)\end{array}$ & $\begin{array}{l}\text { Seas } \\
\text { ona } \\
1 \\
(01 \\
)^{2}\end{array}$ & $\begin{array}{l}\text { A } \\
\text { d } \\
\text { d }\end{array}$ & $\begin{array}{l}\text { Divi } \\
\text { ded } \\
\text { by } 5\end{array}$ \\
\hline
\end{tabular}

Table no 2:-Hazard Assessment

Source: Prepared by author, 2018.

\section{Vulnerability Assessment}

Vulnerability assessment has many things is common with risk assessment. Vulnerability of all GN divisions was assessed using the population density data and construction materials used for the population density in the likely impact area, building standard, economy robust, infrastructure, essential services robust. Vulnerability values a procedure was carried out GN divisions are carried as in the table no.3.

\begin{tabular}{|c|c|c|c|c|c|c|c|c|c|c|c|c|c|c|c|c|}
\hline \multicolumn{3}{|c|}{$\begin{array}{l}\text { What is the } \\
\text { population } \\
\text { density in the } \\
\text { likely impact } \\
\text { areas? }\end{array}$} & \multicolumn{3}{|c|}{$\begin{array}{l}\text { How do you } \\
\text { rate building } \\
\text { standard? }\end{array}$} & \multicolumn{3}{|c|}{$\begin{array}{l}\text { Is the } \\
\text { economy } \\
\text { robust have } \\
\text { weaknesses? }\end{array}$} & \multicolumn{3}{|c|}{$\begin{array}{l}\text { Is the } \\
\text { infrastructu } \\
\text { re sound? }\end{array}$} & \multicolumn{3}{|c|}{$\begin{array}{c}\text { Are Essential } \\
\text { Services Robust }\end{array}$} & \multicolumn{2}{|c|}{$\begin{array}{c}\text { Calculati } \\
\text { on on }\end{array}$} \\
\hline $\begin{array}{l}\mathrm{H} \\
\mathrm{i} \\
\mathrm{g} \\
\mathrm{h}\end{array}$ & $\begin{array}{l}\text { Mod } \\
\text { erat } \\
\text { e } \\
(05)\end{array}$ & $\begin{array}{l}\mathrm{L} \\
\mathrm{o} \\
\mathrm{W} \\
(\end{array}$ & $\begin{array}{l}\mathrm{P} \\
\mathrm{o} \\
\text { or } \\
(1\end{array}$ & $\begin{array}{l}\text { M } \\
\text { e } \\
d \\
(\end{array}$ & $\begin{array}{l}\text { Go } \\
\text { od } \\
(0 \\
1)\end{array}$ & $\begin{array}{l}\mathrm{W} \\
\mathrm{e} \\
\mathrm{a} \\
\mathrm{k}\end{array}$ & $\begin{array}{l}\text { M } \\
\text { e } \\
\text { d } \\
(\end{array}$ & $\begin{array}{l}\text { Ro } \\
\text { bus } \\
\mathrm{t} \\
(01\end{array}$ & $\begin{array}{l}\text { Po } \\
\text { or } \\
(1 \\
0)\end{array}$ & $\begin{array}{l}\text { Med } \\
\text { ium } \\
(05)\end{array}$ & $\begin{array}{l}\text { Go } \\
\text { od } \\
(0 \\
1)\end{array}$ & $\begin{array}{l}\text { W } \\
\text { ea } \\
k \\
(1\end{array}$ & $\begin{array}{l}\text { Med } \\
\text { ium } \\
(05)\end{array}$ & $\begin{array}{l}\text { Ro } \\
\text { bus } \\
\mathrm{t} \\
(01\end{array}$ & $\begin{array}{l}\text { A } \\
\text { d } \\
\text { d }\end{array}$ & $\begin{array}{l}\text { Divi } \\
\text { ded } \\
\text { by } 5\end{array}$ \\
\hline
\end{tabular}

Table no 3:-Vulnerability Assessment 


\begin{tabular}{|l|l|l|l|l|l|l|l|l|l|l|l|l|l|l|l|}
\hline( & & 0 & $0)$ & 0 & & ( & 0 & & & & & $0)$ & & & \\
0 & & 1 & & 5 & & 1 & 5 & & & & & & & \\
) & & & & ) & & 0 & ) & & & & & & & \\
\hline
\end{tabular}

Source: Prepared by author, 2018.

The vulnerability assessment is the process of identifying, quantifying and prioritizing the vulnerabilities in a system. Vulnerability from the perspective of disaster management means assessing the threats from potential hazards to the population and infrastructure. It may be conducted in the political, social, economic or environmental fields.

\section{Manageability Assessment}

Manageability assessment were considered of these elements such as GN level committee, public awareness on disaster, active participation of the stakeholders, perfect GN disaster management plan available, warning mechanism established in this study area. These elements were considered of the flood risk mapping and analyzing.

Table no 4:-Manageability Assessment

\begin{tabular}{|c|c|c|c|c|c|c|c|c|c|c|c|c|c|c|}
\hline \multicolumn{3}{|c|}{$\begin{array}{c}\text { GN level committees } \\
\text { active } \\
?\end{array}$} & \multicolumn{3}{|c|}{$\begin{array}{c}\text { Public awareness on } \\
\text { disasters? }\end{array}$} & \multicolumn{2}{|c|}{$\begin{array}{c}\text { Communit } \\
\text { y Hazard } \\
\text { Mapping } \\
\text { Done with } \\
\text { Active } \\
\text { Participati } \\
\text { on of the } \\
\text { stakeholde } \\
\text { rs? }\end{array}$} & \multicolumn{2}{|c|}{$\begin{array}{c}\text { Perfect } \\
\text { GN } \\
\text { Disaster } \\
\text { Managem } \\
\text { ent Plans } \\
\text { available }\end{array}$} & \multicolumn{3}{|c|}{$\begin{array}{c}\text { Appropriate Early } \\
\text { Warning } \\
\text { Mechanism } \\
\text { Established }\end{array}$} & \multicolumn{2}{|c|}{ Calculation } \\
\hline $\begin{array}{l}\text { Goo } \\
\text { d } \\
(10)\end{array}$ & $\begin{array}{l}\text { Moder } \\
\text { ate } \\
(05)\end{array}$ & $\begin{array}{l}\text { Wea } \\
\mathrm{k} \\
(01)\end{array}$ & $\begin{array}{l}\text { Goo } \\
\text { d } \\
(10)\end{array}$ & $\begin{array}{l}\text { Moder } \\
\text { ate } \\
(05)\end{array}$ & $\begin{array}{l}\text { Wea } \\
\mathrm{k} \\
(01)\end{array}$ & $\begin{array}{l}\text { Yes } \\
(10)\end{array}$ & $\begin{array}{l}\text { No } \\
(01)\end{array}$ & $\begin{array}{l}\mathrm{Ye} \\
(10\end{array}$ & $\begin{array}{l}\mathrm{N}_{\mathrm{r}} \\
(0\end{array}$ & $\begin{array}{l}\text { Goo } \\
\text { d } \\
(10)\end{array}$ & $\begin{array}{l}\text { Mode } \\
\text { ate } \\
(05)\end{array}$ & $\begin{array}{l}\mathrm{W} \\
\mathrm{k} \\
(0\end{array}$ & $\begin{array}{l}\mathrm{A} \\
\mathrm{d}\end{array}$ & \begin{tabular}{|l} 
Divid \\
ed by \\
5
\end{tabular} \\
\hline
\end{tabular}

Source: Prepared by author, 2018.

\section{Results and Discussion: -}

To build a GIS model for flood hazard assessment evaluated based on the research area land use, elevation, slope, distance from river finally it was identified the region id facing more flood hazard or no other than that some area some parameters based on hazard score, vulnerability score, manageability score was identified as a risk score. The land use of the area is mostly dominated by forest, which covered an area of $525621 \mathrm{sq} \mathrm{km}$ and it is about $26 \%$ of the total area. Other land use classes, like inland water covered an area of 449051sq km (22\%), paddy covered 225617 (11\%) of the total area, chena $443525(22 \%)$ of the total area. The overall classification accuracy was derived as, respectively.

Maximum altitude of $200 \mathrm{~m}$ and slope of 12 degree are found in the Vavuniya district of this study area indicating rugged terrain, whereas going towards the town area became very smooth. Elevation database were reclassified in to five groups. Elevation classes $0-25,25$ to 50,50 to 75,75 to 100 , more than $100 \mathrm{~m}$ cover total area $1668415 \mathrm{sq} \mathrm{km}$. About (13\%) 236588sq km area are located above $100 \mathrm{~m}$ in low risk. Of the classes that ranged up to 0-25, 25-50 altitude covered an approximate area of $1339839(71 \%)$ and are marked as very high, high potential to flood. Using Zonal geometry as table was calculated in the elevation. (Table no.5)

Table no 5:-Elevation Characteristics of the Study Area after Reclassification

\begin{tabular}{|c|c|c|c|}
\hline Value & Elevation & Area $\left.\mathbf{( k m}^{2}\right)$ & Area \% \\
\hline $\mathbf{1}$ & $0-25$ & 1180094 & 63 \\
\hline $\mathbf{2}$ & $25-50$ & 159745 & 8 \\
\hline $\mathbf{3}$ & $50-75$ & 208934 & 11 \\
\hline $\mathbf{4}$ & $75-100$ & 96054 & 5 \\
\hline $\mathbf{5}$ & More than 100 & 23588 & 13 \\
\hline
\end{tabular}



TOTAL
1668415
100

Slope database were reclassified in to five groups. Slope classes 0-0.3, 0.3-1.8, 1.8-2.3, 2.3-4.6, more than 4.6 cover total area $1881418 \mathrm{sq} \mathrm{km}$. About $73325 \mathrm{sq} \mathrm{km}$ area are located above 2.3 in low risk of the classes that ranged up to 0-1.8 slope covered an approximate are of $1702326 \mathrm{sq} \mathrm{km}(89 \%)$ and are marked as very high, high potential to flood. Using zonal geometry as table was calculated in the slope area percentage. (Table no.6)

Table no 6:-Slope Characteristics of the Study Area after Reclassification

\begin{tabular}{|c|c|c|c|}
\hline Value & Slope & Area $\left.\mathbf{( k m}^{\mathbf{2}}\right)$ & Area \% \\
\hline $\mathbf{1}$ & $0-0.3$ & 1365885 & 73 \\
\hline $\mathbf{2}$ & $0.3-1.8$ & 306441 & 16 \\
\hline $\mathbf{3}$ & $1.8-2.3$ & 132767 & 7 \\
\hline $\mathbf{4}$ & $2.3-4.6$ & 63173 & 3 \\
\hline $\mathbf{5}$ & More than 4.6 & 13152 & 1 \\
\hline TOTAL & & $\mathbf{1 , 8 8 1 , 4 1 8}$ & $\mathbf{1 0 0}$ \\
\hline
\end{tabular}

Weighted sum operation in spatial analysis extension of Arc GIS10 was followed in integrate all Normalized weighted index and to generate a spatial resolution flood risk database. Flood risk index values of the output database rage from low, to very high. Flood risk data was reclassified in to four categories through a manual classification method as low risk, medium risk, high risk, very high risk. low risk refers to zones where the chances of flood occurrences are above more than 0 . High, very high risk refers to the area where flood can eventuate due to seasonal as well as heavy rain fall. The medium risk is considered along the areas that might be occasionally inundated in the seasons. (Map no.3)

Map no 3:-Flood Hazard Index Map in the Study Area

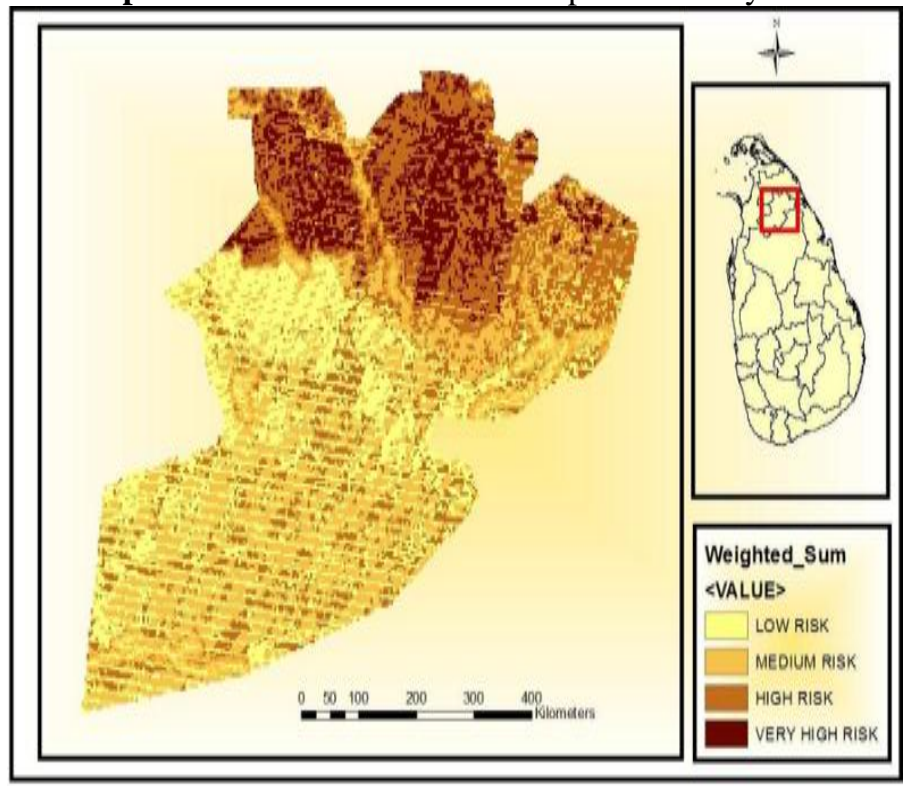

Source: Prepared by author using geographic information system, 2018

The hazard score map with spatial reference to the Vavuniya north, Unchalkaddy, Olumadu, Paranthan as well as in Vavuniya, Pampaimadu, Thandikulam, Echchankulam and Vengalacheddikulam division there are three GN divisions such as Andiyapuliyankulam, Chiristhavakulam, Kandasamynagar part are high hazard prone areas in Vavuniya district. (Map no.4) 
Map no 4:-Flood Hazard Score Map in the Study Area

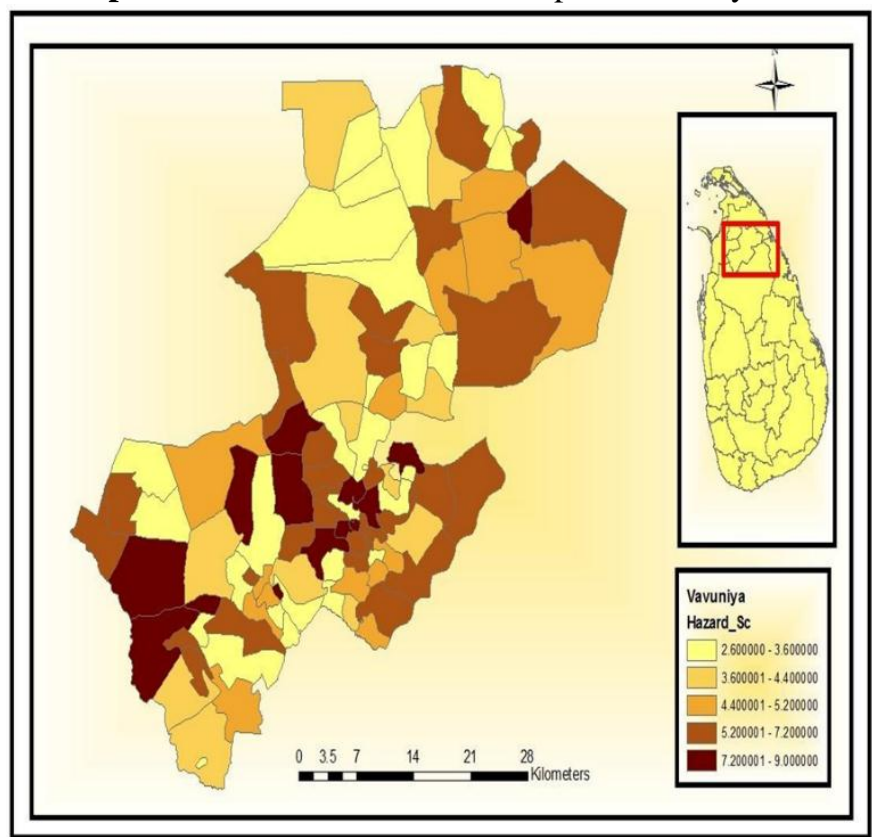

Source: Prepared by author using geographic information system, 2018

The vulnerability score map with spatial reference to the Vavuniya north there is the Kulavisudaan, in Vavuniya, such as Echchankulam, and Marakkarampalai and Vengalacheddikulam division Chiristhavakulam, Multhaliyarkulam, and Sinnasipuliyankulam GN divisions are highly vulnerable areas in Vavuniya district. (Map no.5)

Map No 5:-Flood Vulnerability Score Map in the Study Area

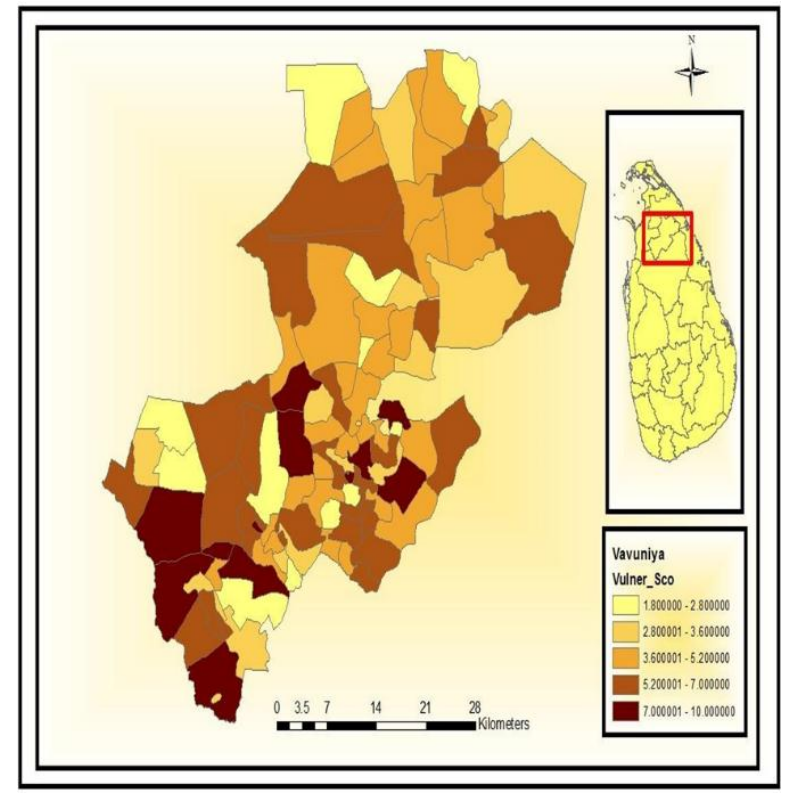

Source: Prepared by author using geographic information system, 2018

The manageability score map with spatial reference in to the Vavuniya north, Ananthapuliyankulam GN division and in Vavuniya, Maruthankulam and Palamodai and Vengalacheddikulam such as Periyathampanai part are high hazard prone areas in Vavuniya district. (Map no.6) 
Map no 6:-Flood Manageability Score Map in the Study Area

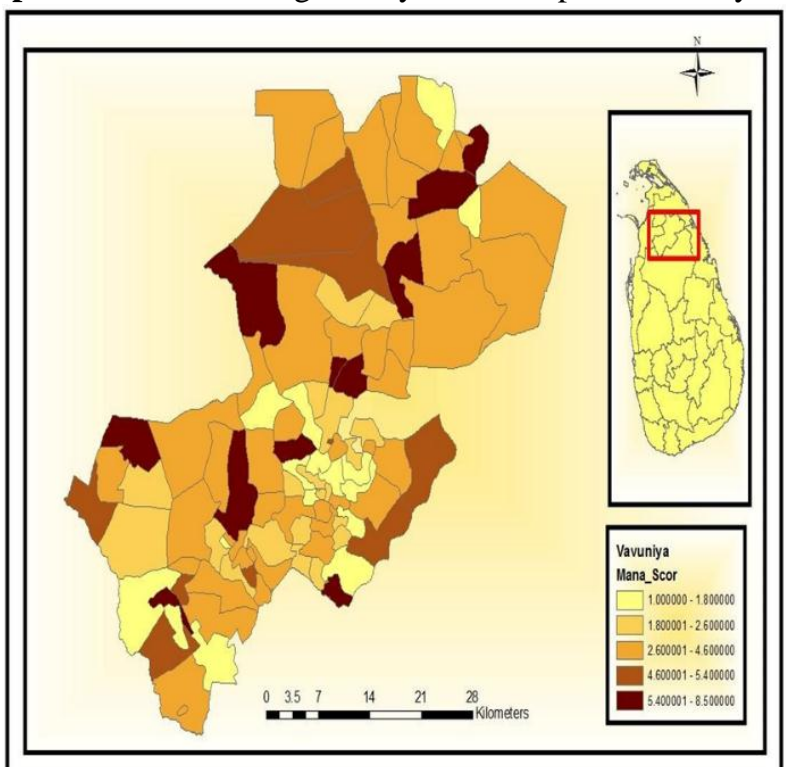

Source: Prepared by author using geographic information system, 2018

Risk assessments the expected degree of loss due to a particular natural phenomenon. Risk analysis can be defined as a systematic use of available information to determine how often specified events may occur and the magnitude of their likely consequences.

Risk score map with spatial references Vavuniya north, such as Kulavisuddaan, in Vavuniya such as Echankulam and Vengalacheddikulam such as Christhavakulam part are high hazard prone area in Vavuniya district. (Map no.7)

Map no.7:-Flood Risk Score Map in the Study Area

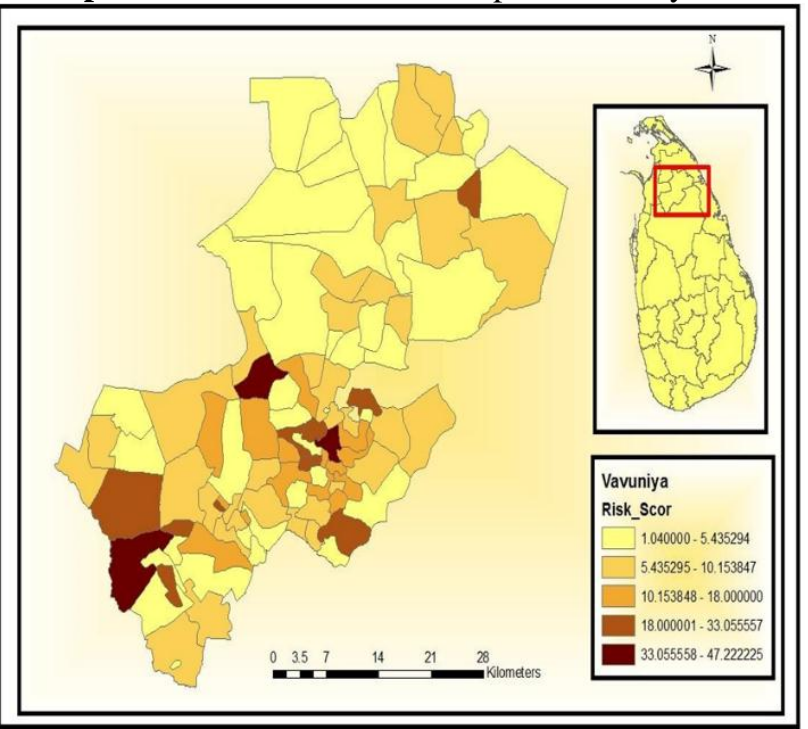

Source: Prepared by author using geographic information system, 2018

An attempt was made to identify the flood hazard zone in Vavuniya district using GIS plat form. In this research, a flood risk map was developed base on the multi-criteria decision approach (MCDA) using different geo spatial data sets, like elevation, slope, distance from river and land use characteristics. The validation report suggests that MCDA and GIS techniques are very powerful method in flood risk analysis and mapping. 
The variables used in the development of flood hazard index were parameters from flood hazard derived flood risk map, it can be concluded that only 4 DSD division out of in safer zone while other were in danger zone. Thus, it is necessary to implement appropriate preventive strategies for the flood prone GN division in order to avoid the potential flood disaster.

Further, the active process of these activities finally the last mile people ensure their active involvement in this risk assessment. The Hazard score map with spatial references Vavuniya north, Vavuniya, and Vengalacheddikulam are high hazard prone areas in Vavuniya district. The vulnerability score map with spatial references Vavuniya north, Vavuniya and Vengalacheddikulam are highly vulnerable areas in Vavuniya district. The manageability score map with spatial references Vavuniya north, Vavuniya, and Vengalacheddikulam are highly hazard prone areas in the district. The risk score map with spatial references Vavuniya, Vavuniya south and Vengalacheddikulam are highly hazard prone areas in Vavuniya district.

\section{Conclusion:-}

The flood situation in Vavuniya district of the northern region of Sri Lanka depends on the rain fall. People of the region should be aware of the effects of flood and the mitigation measure of flood. The following recommendation are given to mitigation the flood impacts, monitor the flood and to adopt the early warning system. There are no early warning systems to predict the flood hazards in the study area. According to this research there are some findings. As per these findings in flood seasons, the vulnerable area as have to be forecast to the people to reduce the impact on agriculture due to hazards.

Government has to instruct to the people of the Vavuniya district, to be aware during the north east monsoon season (December, January, and February) and second inter monsoon season (October and November) to avoid the severe impacts due to flood occurrences. Because high number of floods have been occurred during above seasons in the study area. Building, new tanks and ponds renovating the existing tanks and ponds will reduce the flood damage impact in the study area. So, there should be an attention in the monitoring during the second inter monsoon season (SIMS) and north east monsoon season (NEMS) because during this season this area is receiving much rain fall and caused to the flood impacts.

The unplanned construction of walls, road, deforestation and gardening are the major cause for the damage of the natural and artificial drainage pattern in the study area. Due to the disturbance of the drainage pattern, rain water storage in the city areas, settlements areas and the farm field create flood vulnerability. New drainage and renovation of the old drainage systems should help avoid the flood damages in the above places of the study area.

Identification flood prone areas should help to assist authorities during emergency. Geographical information systems and remote sensing techniques will help to adopt measurers successfully in this study area. Application of advanced techniques in soil physics, geotechnical, engineering, GIS, and remote sensing for flood risk reduction are also needed. Stakeholder participation flood control measures planned without participation of the affected communities and other stakeholders are unsustainable as they do not meet the needs of relevant stakeholders. These situations can be overcome by establishing participatory planning process. In this context, decision making is a combination of top-down and bottom-up approaches which enables the involvement of all stakeholders on the basis of equity. The stakeholders consist of responsible municipal authorities, river basin organizations, regional development authorities; academic institutions, private sector; NGOs and concerned citizens and communities. The involvement of stakeholder knowledge from different perspectives together enables a coherent understanding of flood risks. Members of affected communities have the chance to express the community needs and to promote the integration of their demands in the decision making. Stakeholder involvement allows for identification and implementation of flood effective and sustainable management measures because the majority of stakeholders support them.

In this context, this study would help to predict to flood hazards and create awareness of the risk to be caused by flood to plan the future activities related to such hazards and mitigation in the Vavuniya district. Disaster management center has to implement special projects to avoid flood and vulnerability in the study area. There is a need to conduct awareness. Public awareness program such as workshops, seminars to be arranged by government, NGO. It will be help to reduce the flood hazards. 


\section{References:-}

1. Brauch, H.G. (2005). Threats, Challenges, Vulnerabilities and Risks in Environmental and Human Security. Publication of United Nations University Institute for Environment and Human Security. Source no, 1/2005.

2. Christenson, E., Elliott, M., Banerjee, O., Hamrick, L., \& Bartram, J. (2014). Climate-Related Hazards: A Method for Global Assessment of Urban and Rural Population Exposure to Cyclones, Droughts and Floods. International Journal of Environmental Research and Public Health, 11(2), 2169-2192. http://doi.org/10.3390/ijerph110202169

3. Correia, F. N., Saraiva, M. G., \& Silva, F. N. (1997). Floodplain Management in Urban Developing Areas. submitted to publication in Water Resource Manage, Kluwer Academic Publishers. Dordrecht, the Netherlands.

4. Delley, M., Chen R.S., Deichmann, U., Lerner-Lam A.L., Arnold, M., Lyon, B., \& Yetman, G. (2005). Natural Disaster hotspots: a global risk analysis. International Bank for Reconstruction and Development. The World Bank and Columbia University, Washington, DC.

5. Doocy, S., Daniels, A., Murray, S., \& Kirsch, T. D. (2013). The Human Impact of Floods: a Historical Review of Events 1980-2009 and Systematic http://doi.org/10.1371/currents.dis.f4deb457904936b07c09daa98ee8171a

6. IPCC, (2007). An Assessment of the Intergovernmental Panel on Climate Change. IPCC Secretariat, World Meteorological Organization, Geneva, Switzerland.

7. Lowe, D., Ebi, K. L., \& Forsberg, B. (2013). Factors Increasing Vulnerability to Health Effects before, during and after Floods. International Journal of Environmental Research and Public Health, 10(12), 70157067. http://doi.org/10.3390/ijerph10127015

8. RPA, (2004). Evaluating a multi criteria analysis methodology for application to flood management and coastal defence appraisals, Rand Technical Report.

9. Rodriguez-Llanes, J. M., Ranjan-Dash, S., Mukhopadhyay, A., \& Guha- Sapir, D. (2016). Looking upstream: enhancers of child nutritional status in post-flood rural settings. PeerJ, 4, e1741. http://doi.org/10.7717/peerj.1741

10. UNISDR, UNDP, IUCN, (2009). Making disaster risk reduction gender sensitive. policy and practical guidelines. Geneva, Switzerland: UNISDR, UNDP \&IUCN. 